\title{
An Analysis of the Use of Secondary Reinforcers by Pre-School Teachers for the Students with Special Needs in Inclusive Classes
}

\author{
Tansel Yazıcıŏglu \\ Correspondence: Tansel Yazıcıoğlu, Assist. Prof., Nevsehir Haci Bektas Veli University, Faculty of Education, Special \\ Education Department, Nevsehir, Turkey.
}

\author{
Received: December 14, 2019 Accepted: January 17, 2020 Online Published: February 7, 2020 \\ doi:10.11114/jets.v8i4.4655 \\ URL:https://doi.org/10.11114/jets.v8i4.4655
}

\begin{abstract}
Reinforcement is one of the widely used practices in today's educational environments. Teachers often use reinforcement as a form of discipline in the classroom, and these reinforcements allow students to learn new ideas, skills, and rules. Reinforcers can be used effectively in teaching of the social and academic skills as well as in reducing or eliminating problem behaviors. Therefore, this study aims at identifying how pre-school teachers in inclusive classes employ secondary reinforcers for the students with special needs. The study is designed as a descriptive research. The participants of the study are four pre-school teachers working in Ankara who teach students with special needs. In this study, the data were collected through the Teacher and Student Information Form and Learned Reinforcement Checklist which was developed by the author. The findings of the study indicate that the participants mostly use social reinforcers. In other words, they all prefer to use social reinforcers such as praise words and applauding for the students with special needs. The findings of the study indicate that the participants employ limited number of activity reinforcers and all teachers participated in the study employed token reinforcers for the students with special needs.
\end{abstract}

Keywords: reinforcement system, token reinforcers, behavior change, well done, applaud

\section{Introduction}

Pre-school inclusive education is considered by many specialists and teachers to be one of the most useful practices for children with special needs (Henninger and Gupta, 2014; Odom and McEvoy, 1990).Inclusive education is reported to improve the linguistic development and social capablities of the children with special needs, their early literacy skills(Green, Terry and Gallagher, 2014; Rafferty, Piscitelli and Boettcher, 2003) and their positive social interactions with peers (Hollingsworth and Buysse, 2009). Kircaali-İftar (1998) argues that pre-school education period is the most production period for inclusive education and that it positively contribute to children's subsequent educational life.

It is certain that one of the major elements in pre-school inclusive education is teachers. Odom (2000) emphasizes that teachers play a significant role in successful and quality inclusive education. The quality of education can be improved when teachers enrich their teaching capacities based on the requirements of the period (Saracho, 1998). The use of appropriate teaching methods and strategies, adapting teaching and making arrangements to allow for children to acquire desired behavior in the teaching environment are closely related to the success of inclusive education practices (Bricker, 2000).

Teachers make various arrangements to prevent the occurrence of problem behaviors in their classrooms. However, some children may continue to exhibit problem behavior even in well-organized educational settings (Yücesoy Özkan, 2013). One of the most effective techniques to prevent problem behaviors among students is to reinforce positive behaviors. Focusing on positive behaviors and reinforcing these behaviors will provide positive experiences for children and therefore, will prevent the occurrence of problem behaviors as much as possible, and will ensure that positive behaviors will increase and be permanent.

Reinforcement is one of the widely used practices in today's educational environments. Reinforcement is the process of adding stimuli to the environment or withdrawing the stimuli from the environment in a way that increases the likelihood of the behavior it follows or causes the behavior to continue (Vuran and Olçay Gül, 2017). Teachers often use reinforcement as a form of discipline in the classroom, and these reinforcement sallow students to learn new ideas, skills, and rules (Charles and Senter, 2004).

Reinforcers are categorized into two subgroups, namely positive reinforcers and negative reinforcers. Adding a pleasant 
stimulus to the environment immediately after a behavior has taken place and increasing the likelihood of future repetition of the behavior through this stimulus is called positive reinforcement (Alberto and Troutman, 2013; Cooper, Heron and Heward, 2007; Webber and Scheuermenn, 2008). Negative reinforcement is the withdrawal or removal of a repulsive stimulus to increase the likelihood or frequency of a behavior in the future (Akmanoğlu, 2012; Alberto and Troutman, 2013; Webber and Scheuermenn, 2008).Reinforces that meet the vital needs of an individual without any learning experience or conditioning and create a pleasant situation in the individual are called primary or unlearned reinforcers (Alberto and Troutman, 2013; Cooper, Heron and Heward, 2007;Kurt, 2012;Webber and Scheuermenn, 2008). Secondary reinforcers are about to meet the vital needs of individuals and to provide natural motivation. Food, beverages, air, heat, shelter, sexuality and sensory stimuli are some types of primary reinforcers (Wolery, Bailey and Sugai, 1988). Stimuli that are not intended to meet the individual's vital activities, but which are pleasant to the individual and create a positive effect are called learned or secondary reinforcements (Alberto and Troutman, 2013; Cooper, Heron and Heward, 2007; Kurt, 2012; Schloss and Smith, 1993; Sulzer-Azaroff and Mayer 1991; Webber and Scheuermenn, 2008; Wolery, Bailey and Sugai, 1988). Learned or secondary reinforcers are categorized into four: social reinforcers, activity reinforcers, object reinforcers and token reinforcers (Tekin-İftar, Kırcaali-İftar, 2012). Social reinforcers include social meanings such as establishing physical interaction, showing intimacy, using words of praise, directing attention using gestures and facial expressions (Cooper, Heron and Heward, 2007). Activity reinforcers refer to the activities in which an individual is content to be interested and actively engaged. Some examples of such reinforcers are the daily activities such as playing ball, reading books, listening to music, playing basketball, having lunch with teachers, going to a game and going to the zoo (Cooper, Heron and Heward, 2007). Any object that is visible and tangible fitting the interests of the individual in terms of his age, and that when he attains arouses satisfaction in the individual is called activity reinforcer. Some examples include balls, tablets, computers, books, cartoon heroes, toys and car accessories. For instance, for a child who is interested in football and closely follows a team, the team's accessories, sports clothes and match tickets can be used as effective object reinforcers (Besler and Süzer, 2018). Token reinforcers are mostly as money, news paper coupons, tokens which are not meaningful in themselves but can be converted into other reinforcers. (Vuran and Olçay Gül, 2017). Token reinforcement is a reinforcement process in which non-reinforcing symbols (brand, star, etc.) are presented immediately after the target behavior, after which a predetermined amount of symbols has been reached and replaced with the desired reinforcers (Kerr and Nelson, 1998). A typical token reinforcement system includes a list showing target behaviors, their respective symbols, and reinforcement costs. Students gain these symbols whenever they exhibit an appropriate behavior and but a reinforcers contained in the list (Lyon and Lagarde, 1997).

As in other educational settings, the success of the children with special needs in the inclusive classes is only possible if their teachers employ reinforcement processes and effective reinforcers (Özyürek, 2001; Uysal, 2001). To this end teachers should identify the reinforcers to be used. They should closely monitor which behaviours are reinforced, present the reinforcers immediately after the desired behaviours and prefer to secondary reinforcers to contribute the student achievement (Özyürek, 2001; Kırcaali-İftar, 1998; Uysal, 2001).

If preschool teachers use very little reward or praise for children to exhibit the desired behaviors, it negatively affects teacher-child interaction and therefore, the learning environment in the classroom (Hutchings et. al., 2007). Carpenter and Mc Kee-Higgins (1996) stated that the control of appropriate behavior among students should be preventive and that recognizing and rewarding appropriate behavior create a positive school climate. Bruns and Mogharberran (2009) argued that it is necessary for preschool teachers to know the appropriate strategies and intervention techniques to increase interaction among students and to develop positive behavior to improve the quality of inclusion practices. Odom (2000), on the other hand, stated that the ability of students with special needs placed in preschool inclusive classes to benefit from the educational environment depends on the competence of preschool teachers to implement the proper intervention programs. Preschool education is a critical period for children with special needs to acquire the basic communication skills necessary to facilitate their adaptation to society in later years. Teachers of children with special needs play a major role in this period (Allen and Cowdery, 2005; Lindsay, 2007)

Some of the studies carried out in Turkey dealt with the use of reinforcers by teachers for the students with special needs attending inclusive classrooms. For instance, Çiftçi, Yıkmış and Altun (2001) analyzed the use of reinforcers by teachers for the students with special needs attending inclusive classrooms. It is concluded that teachers do not reward students with special needs and that they even are not aware of such students. Çelik and Eratay (2007) examined the use of reinforcers and punishment by the teachers for the students with mental disability in inclusive classrooms and special education classes. It is found that teachers used several types of reinforcers in classes such as verbal reinforcers, social reinforcers, object reinforcers, token reinforcers and food reinforcers. Sucuoğlu, Demirtaşlı and Güner (2009) observed the teaching activities of 201 teachers per one class hour in inclusive education settings and concluded that only $27.36 \%$ of teachers rewarded the students with special needs for their appropriate behaviours. In addition, it is also found that 
the majority of the teachers observed do not employ reinforcers in a systematical way and do not have necessary information about the use of effective reinforcers. Uysal (2001) emphasizes that teachers do not provide enough reinforcement to the students and that teachers' knowledge and skills about the use of effective reinforcers should be increased. Olçay Gül and Vuran (2015) analyzed the views of fourteen primary school, secondary school and high school students attending regular classes about inclusive education practices. Seven students reported that their teachers do not use rewards in the classroom and the remaining seven students reported that they are rewarded by their teachers. GünerYıldız and Erdem (2018) examined the ideas and practices of special education teachers and classroom teachers regarding the use of awards in special education and general education. They concluded that two groups of teachers differ in regard to the use of rewards and that the reason for such differences stems from their teaching training programs. The findings given above suggest that the use of reinforcers by pre-school teachers in inclusive classes should be examined in detail. Because the reinforcement system is a behavior change strategy that can be used at almost all educational levels. Reinforcers can be used effectively in teaching of the social and academic skills as well as in reducing or eliminating problem behaviors. For this reason, it is significant to analyse how preschool teachers teaching in inclusive classes use reinforcers that are effective in managing the behaviors of students with special needs and increasing their social and academic skills. Therefore, the study aims at identifying how pre-school teachers in inclusive classes employ secondary reinforcers for the students with special needs. In line with this aim the study attempts to answer the following research questions:

1. Which secondary reinforcers do pre-school teachers use for the students with special needs in inclusive classes?

2. At which level do pre-school teachers use the secondary reinforcers for the students with special needs in inclusive classes?

\section{Method}

The study is designed as a descriptive research. Below information is presented in regard to the participants, data collection tools, and data collection procedures and data analysis.

\subsection{Participants}

The participants of the study are four pre-school teachers working in Ankara who teach students with special needs. The school where the study was conducted consists of two floors, the ground floor and the first floor. All classrooms are in the first floor. There are also the room of the school principal, officer study room, library, parents' interview room, kitchen and sinks. In the ground floor there are dining hall, kitchen, multi-purpose hall, game rooms and boiler room. There are five classrooms at the pre-school and four of them are inclusive classes. One classroom is for the children aged three, another is for children aged four, and two classrooms are for children aged five. In the classes for children aged five there are one inclusive student. There are also one inclusive student in the classes for children aged three and for children aged four. The school is a half day school, and in the afternoon, optional children's club activities are carried out. There are a school principal, six teachers, an officer, two cleaning assistants, a cook and an assistant cook at the school. One of the teachers is on the staff of the district directorate of national education and works temporarily at the school. This teacher takes part in the activities of the children's club. The study was carried out in inclusive classes. All teachers participated in the study are female. Three teachers are the graduates of the four-year pre-school teaching programs and one the four-year Child Development and Home Economics program. Information on the age, experience and age groups of the teachers and the gender, age and diagnosis of the students with special needs are given in Table 1 and Table 2, respectively.

Table 1. Information about the teachers participated in the study

\begin{tabular}{llll}
\hline Participants & Age & Teaching Experience & Age group of the students \\
\hline Teacher 1 & $35-46$ & 23 years & $5-6$ \\
Teacher 2 & $46-51$ & 32 years & 5 \\
Teacher 3 & $29-34$ & 13 years & 3 \\
Teacher 4 & $35-46$ & 24 years & 4 \\
\hline
\end{tabular}

Table 1 shows that two teachers are aged between 35and 46, one is aged between 46 and 51 and another one is between 29 and 34. One of the teachers has 23 years of teaching experience, another one has 32 years of teaching experience, another has 13 years of teaching experience and the last one has 24 years of teaching experience. Teacher 1 works in the classroom for the children aged five-six, Teacher 2 works in the classroom for the children aged five, Teacher 3 works in the classroom for the children aged three and Teacher 4 works in the classroom for the children aged four. 
Table 2. Information on the students with special needs who participated in the study

\begin{tabular}{llll}
\hline Students with special needs & Gender & Age & Diagnosis \\
\hline Students with special needs 1 & Male & 6 & Autism spectrum disorder \\
Students with special needs 2 & Male & 5 & Linguistic and speech disorder \\
Students with special needs 3 & Male & 3 & Linguistic and speech disorder \\
Students with special needs 4 & Female & 4 & Attention deficit and hyperactivity
\end{tabular}

As can be seen in Table 2 there are three male students with special needs and one female student with special needs. One of the students is six-year old (attending the class for the children aged five), one of them is five-year old, one of them is four-year old and one of them is three-year old. Two students have the linguistic and speech disorder, one has the autism spectrum disorder one has the attention deficit and hyperactivity. All of these students was diagnosed as those individuals with special needs and the verdict of the Guidance Research Centers (GRCs) required that they should be given special education services.

\subsection{Data Collection Tool}

In this study, the data were collected through the Teacher and Student Information Form and Learned Reinforcement Checklist which was developed by the author.

\subsubsection{Information Forms for Teachers and Students}

One of the forms was used to collect information about the age, teaching experience and grade they of the teachers participated in the study. The other form was developed to have information about the age, gender and diagnosis of the students with special needs.

\subsubsection{Checklist for Secondary Reinforcers}

The success of a behavior change attempt or an educational program is closely related to the identification and use of effective reinforcers by the practitioner and the researcher. An object, activity or phenomenon can have a distinct reinforcing effect for each individual. Different strategies and practices are used to determine effective reinforcers, including interviews, observations and stimulus based trials (Alberto and Troutman, 2013). In developing a checklist for the secondary reinforcers a two-step process was followed. At the first step the related studies were reviewed to find out the secondary reinforcers (token reinforcers, object reinforcers, activity reinforcers and social reinforcers) used at the pre-school education, and a list was developed. This list was reviewed by two specialists who have expertise on the analysis of applied behavours. They confirmed the appropriateness of the list. At the second step twelve teachers working at pre-education schools and six teachers working in kindergarten were randomly selected. They were asked to develop a list of secondary reinforcers. They were also asked to review the empty checklists which only included the headings of token reinforcers, social reinforcers, activity reinforcers and object reinforcers. These teachers agreed to voluntarily fill in the lists. The list developed by the author and those developed by the teachers were compared. The suggestions of the teachers regarding the secondary reinforcers were added to the lists. These were the secondary reinforcers such as go to the park, sticking leaves on the tree, apple painting, map painting and medal insertion.

\subsection{Data Collection Procedure and Data Analysis}

Before collecting the data, the process of obtaining permission from the school principal, the teachers working at the school and the parents of the children was carried out indicating that they were willing to participate in the study. During this process, a meeting was held with teachers by going to the school. During the meeting, the teachers were informed that some of the class activities would be recorded, and the behavior of students with special needs and their reactions would be examined. Following the meeting the form for teachers' background was administered to the teachers by the author. The forms for the students with special needs were filled based on the medical reports and the reports given by the GRCs. The consent form were sent to the parents. Following the completion of consent process the art activities in each class were recorded for thirty minutes. For the groups aged five recordings were done on Monday and for the groups aged three and four recordings were done on. The recordings were done between 3 December 2018 and 28 December 2018 producing a total of eight-hour recordings.

Concerning the realibility and interrater reliability for the observations carried out in the classrooms two teachers who were not among the participants of the study watched the video recordings to analyse whether or not the data were collected in accordance with the secondary reinforcers list. The reliability coefficient for observation was identified using the following formula: "mutually agreed number of secondary reinforcers / agreement + disagreement for the number of reinforcers x 100" (Casey and McWilliam, 2008). The coefficient for co observers was found to be $92 \%$. Given that this coefficient is reported to be $80 \%$ (Tekin-İftar, 2012) the necessary co observer reliability is granted in the 
study. Concerning the reliability for co-observers two specialists analyzed the data collected. One of them was a special education expert who was a graduate of the department of teaching of mentally handicapped at Ankara University and who was working as a special education teacher. The other one was a faculty member on the related field. It is reported that for the co observer reliability at least $20 \%$ of the data should be included in the process (Tekin-İftar and Kurcaali-İftar, 2004). For the total eight-hour video recordings the reliability analyses were carried out using $25 \%$ of the total recordings (2hours of recordings). The coefficient for co observer reliability was identified using the formula given above. The coefficient for co observer reliability was found to be $90 \%$.

\section{Results}

This section presents the findings of the study based on the research questions given above.

Findings on the social reinforcers used by the pre-school teachers

Table 3 shows the frequency and type of the social reinforcers used by the pre-school teachers participated in the study.

Table 3. Social reinforcers used by the teachers

\begin{tabular}{llllll}
\hline Reinforcer & Teacher 1 & Teacher 2 & Teacher 3 & Teacher 4 & $\begin{array}{l}\text { Frequency } \\
\text { (f) }\end{array}$ \\
\hline Well done & 18 & 12 & 10 & 11 & 51 \\
Very good & 6 & 1 & 7 & 5 & 19 \\
Super & 2 & - & 1 & - & 3 \\
You are awesome & 1 & - & - & - & 1 \\
I really like it & 5 & - & - & 2 & 7 \\
High five & 2 & - & - & 1 & 3 \\
Applaud & 8 & 4 & 6 & 7 & 25 \\
Touching the face of the student & 9 & - & 1 & - & 10 \\
Hugging the student & 11 & - & - & - & 11 \\
\hline
\end{tabular}

As can be seen in Table 3the most frequently used social reinforcers by the participants are as follows: saying the praise word "well done"to the students, applauding the students, saying the praise word "very nice", hugging the student, touching the face of the student, saying the praise word "I really like it", "high five" and saying the praise words "super" and "you are awesome" to the students.

\section{Findings on the activity reinforcers used by the pre-school teachers}

Table 4 shows the frequency and type of the activity reinforcers used by the pre-school teachers.

Table 4. Activity reinforcers used by the teacher

\begin{tabular}{llllll}
\hline Reinforcer & Teacher 1 & Teacher 2 & Teacher 3 & Teacher 4 & $\begin{array}{l}\text { Frequency } \\
\text { (f) }\end{array}$ \\
\hline Playing a game that the child likes & 2 & - & 3 & 2 & 7 \\
Playing at park & 3 & 2 & - & - & 5
\end{tabular}

Table 4 shows that the teachers used two activity reinforcers. Of them they mostly use the playing of a game that the child likes.

Findings on the object reinforcers used by the pre-school teachers

Table 5 shows the frequency and type of the object reinforcers used by the pre-school teachers.

Table 5. Object reinforcers used by the teacher

\begin{tabular}{llllll}
\hline Reinforcer & Teacher 1 & Teacher 2 & Teacher 3 & Teacher 4 & Frequency (f) \\
\hline Colour pencil & 2 & - & - & - & 2 \\
Toy robot & 3 & - & - & - & 3 \\
Toy car & - & - & 3 & - & 3 \\
\hline
\end{tabular}

As can be seen in Table 5 the participants use colour pencils, toy robots and toy cars as an object reinforcer. They mostly employ toys object reinforcers. 
Findings on the token reinforcers used by the participants

Table 6 shows the frequency and type of the token reinforcers used by the pre-school teachers.

Table 6. Token reinforcers used by the participants

\begin{tabular}{llllcc}
\hline Reinforcer & Teacher 1 & Teacher 2 & Teacher 3 & Teacher 4 & $\begin{array}{l}\text { Frequency } \\
(\mathrm{f})\end{array}$ \\
\hline Smiley face & 1 & 8 & 3 & - & 12 \\
Stars & 2 & 3 & 4 & 1 & 10
\end{tabular}

As can be seen in Table 6 the participants use two types of token reinforcers, namely "smiley face" and "stars". It is also seen that they use smiley face more than stars as token reinforcers.

\section{Discussion}

The findings of the study indicate that the participants mostly use social reinforcers. In other words, they all prefer to use social reinforcers such as praise words and applauding for the students with special needs. However, there are differences between the social reinforcers used by the teachers for the students with special needs. This may be due to the type of disability of children with special needs. For instance, Teacher 1 used more varied social reinforcers for the student with autism spectrum disorder (student with special needs 1) in contrast to other teachers. For instance, only Teacher 1 employed the social reinforcer in the form of hugging the student. Teacher 1 and Teacher 2 used the social reinforcer in the form of touching the student's face. The frequent use of social reinforcers by teachers is important in terms of direct interaction and communication between teacher and children. For instance, in a study investigating the effects of social reinforcers on a female student attending kindergarten and exhibiting little social interaction and playing games with her peers (Allen, Hart, Buel, Harris and Wolf, 1964) the extreme attention by the teacher was used as a social reinforcer. In the study teacher paid attention to the student with special needs when she was playing with her peers, but he did not pay attention to her when she was alone. During her interaction with an adult teacher paid less attention to her. At the end of the study, it was observed that students' one-on-one play behavior with their peers increased, and their solo playing games and playing games with adults decreased. In short, pre-school teachers should use social reinforcers in an effective way in the inclusive classes.

The findings of the study indicate that the participants employ limited number of activity reinforcers. More specifcally, the teachers participated in the study are found to employ only two activity reinforcers. This finding of the study suggests that pre-school teachers use activity reinforcers in a limited way or that they do not prefer to employ such reinforcers. Although the teachers samples in the study use limited number of activity reinforcers, they prefer to use games as activity reinforces which are very good choice for pre-school students. Indeed, games are an active and natural learning environment for children. Monitoring the pre-school students with special needs in inclusive classess is very critical to make them able to interact with their environment and to express their emotions and views.

Another finding of the study is that some of the teachers do not use object reinforcers at all. The teachers participated in the study are found to use more frequently toys as object reinforcers and also, to employ color pencils as object reinforcers. The fact that some teachers never use object reinforcers should be reflected on and discussed. Because the success of behavior change attempts and the educational program depends on the determination of effective and appropriate reinforcers by the teachers. In particular, the use of the object reinforcers requires to have information about children's interests and tendency. Therefore, given that some of the teachers do not use object reinforcers it can be interpreted as either they do not know the interests, tendencies and tastes of the children with special needs, or they do not have necessary information about the process of the effective reinforcer determination. Alberto and Troutman (2013) stated that especially for individuals who cannot express themselves verbally, a selection menu consisting of objects loved by them can be developed primarily in line with the information received from their parents or carers. It is reported that this practice, which is called as reinforcement menu in the related studies, can be preferred as a written or visual material taking consideration the age and cognitive development characteristics of the child with special needs (Cooper et. al., 2007; Scheuermann and Webber, 2002; Sturney and Fitzer, 2007). Based on this information it can be argued that teachers should use object reinforcers effectively and prepare reinforcers list and determine preferred stimuli.

The findings of the study indicate that all teachers participated in the study employed token reinforcers for the students with special needs. More specifically, those teachers working at the classes in which students with linguistic and speech disorder more frequently used token reinforcers. It can be stated that it is very advantageous for the pre-school students with linguistic and speech disorder. The same applies to children with autism and spectrum disorders. In addition, it is reported that token reinforcers are very influential in teaching social and academic skills and in reducing problem 
behaviour (Alberto and Troutman, 2013; Gena, Krantz, Mc Clannahan and Poulson, 1996; Maag, 1999; Maggin, Chafouleas, Goddart and Johnson, 2011; Matson and Boisjoli, 2009; Scholoss and Smith, 1994; Tarbox, Ghezziand Wilson, 2006). In another study Higgins, William and McLaughlin (2001) analyzed the effects of token reinforcers on reducing undesired behaviour. The aim of their study was to reduce the deterioration, loud speaking and inappropriate sitting behaviors of a male student with learning difficulties attending third grade in primary school through the use of token reinforcers. The findings of the present study suggest that the use of token reinforcers reduce such problem behaviours in inclusive classes. On the other hand, the finding indicating that the teachers participated in the study prefer to employ token reinforcers is consistent with the previous findings.

Concerning the types of reinforcers used by the pre-school teachers for the students with special needs it is found that they mostly employ social and token reinforces, but not object and activity reinforcers. In particular, the use of activity reinforcers in inclusive classes is required to increase and improve the social and academic skills of students with special needs. Therefore, teachers working in preschool inclusive classes should use effective reinforcers considering the developmental characteristics of all children, especially children with special needs. In addition, increasing the knowledge and competence of teachers about special education and inclusive education practices working at preschools where inclusive students are educated may have a positive effect on the teaching and learning activities. In particular, training on the use of reinforcements can help teachers manage the inclusive classes more effectively.

The data of the study were collected from a sample of pre-school teachers who taught inclusive students. However, it is thought that the research findings will contribute to the existing literature and future studies. Future studies can be carried out at primary and secondary schools where inclusive students are trained. It is possible to collect data from higher number of teachers. In short, in pre-school inclusive education teachers use secondary reinforcers. However, it is thought that the use of more systematic and scientific reinforcement in the inclusion environments would be more beneficial.

\section{References}

Akmanoğlu, N. (2012). Otizm spectrum bozukluğu olan çocuklara uygun ve yeni davranışların kazandırılması ve arttırılması. In E. Tekin İftar (Ed.), Otizm spectrum bozukluğu olan çocuklar ve eğitimleri (s. 121-182). Ankara: Vize Basin Yayın.

Alberto, P. A., \& Troutman, A. C. (2013). Applied behavior analysis for teachers (9. bask1) New Jearsey: Pearson.

Allen, K. E., \& Cowdery, G. E. (2005). The exceptional child: Inclusion in early childhood education (5th Edition). USA: The Thomson Corporation.

Allen, K. E., Hart, B., Buel, J. S., Harris, F. R., \& Wolf, M. M. (1964). Effects of social reinforcement on isolate behavior of a nursery school child. Child Development, 35, 511-518. https://doi.org/10.1111/j.1467-8624.1964.tb05188.x

Besler, F., \&Süzer, T. (2018). Uygulamalı davranış analizi. In E. Tekin İftar (Ed.), Pekiştirme (s. 214-266). Ankara: Vize Akademik

Bricker, D. (2000). Inclusion: How the scene has changed. Topics in Early Childhood Special Education, 20, 14-19. https://doi.org/10.1177/027112140002000103

Bruns, A. D., \&Mogharberran, C. C. (2009). The gap between beliefs and practices: Early childhood practitioners' perceptions about inclusion. Journal of Research in Childhood Education, 21(3), 229-241. https://doi.org/10.1080/02568540709594591

Carpenter, S. L., \& McKee-Higgins, E. (1996). Behavior management in inclusive classroom. Remedial \& Special Education, 17(4), 195-206. https://doi.org/10.1177/074193259601700402

Casey, A. M., \& McWilliam, R. A. (2008). Graphical feedback to increase teachers' use of incidental teaching. Journal of Early Intervention, 30(3), 251-268. https://doi.org/10.1177/1053815108319038

Çelik, İ., \& Eratay, E. (2007). Kaynaştırma sınıfı ve özel eğitim öğretmenlerinin sınıflardaki zihin engelli öğrencilere yönelik pekiştireç ve ceza uygulamalarının belirlenmesi. Abant İzzet Baysal Eğitim Fakültesi Dergisi, 7(1), 41-57.

Charles, C. M., \&Senter, G. W (2004). Building classroom discipline (8th ed). Boston: Allyn \& Bacon.

Çiftçi, İ., Yıkmış, A., \& Akbaba, A. S. (2001). Kaynaştırma sınıflarında çalışan öğretmenlerin kaynaştırılmış öğrencilere yönelik pekiştireç kullanma durumlarının belirlenmesi. XI. National Special Education Congress free papers. Konya: Eğitim Kitabevi Yayınları, 217-229.

Cooper, J. O., Heron, T. E., \& Heward, W. L. (2007). Applied behaivor analysis (2nd edition). Ohio: Pearson Merrill Prencite Hall. 
Gena, A., Krantz, P. J., McClannahan, L., \& Poulson, C. L. (1996). Training and generalization of affective behavivor displayed by youth with autism. Journal of Applied Behavior Analysis, 29, 291-304. https://doi.org/10.1901/jaba.1996.29-291

Green, K., Terry, N., \& Gallagher, P. (2014). Progress in language and literacy skills among children with disabilities in inclusive early reading first classrooms. Topics in Early Childhood Special Education, 33(4), 249-259. https://doi.org/10.1177/0271121413477498

Güner, Y. N., \& Erdem, R. (2018). Özel Eğitimde ve Genel Eğitimde Ödül Kullanımı: Odak Grup Görüşmeleri. Kastamonu Eğitim Dergisi, 26(1), 29-37. https://doi.org/10.24106/kefdergi.375052

Henninger, W. R., \& Gupta, S. S. (2014). How do children benefit from inclusion? In S. S. Gupta, W. R. Henninger, IV, \& M. E. Vinh (Eds.), First steps to preschool inclusion: How to jumpstart your program wide plan (pp. 33-61). Baltimore, MD: Paul H. Brookes Publishing.

Higgins, J. W., Williams, R. L., \& McLaughlin, T. F. (2001). The effects of token economy employing instructional consequences for a third-grade with learning disabilities. A database case study. Education and Treatment of Children, 24, 99-106.

Hollingsworth, H. L., \& Buysse, V. (2009). Establishing friendships in early childhood inclusive settings: What roles do parents and teachers play? Journal of Early Intervention, 31(4), 287-307. https://doi.org/10.1177/1053815109352659

Hutchings, J., Daley, D., Jones, K., Martin, P., Bywater. T., \& Gwyn, R. (2007). Early results from developing and researching the webster-stratt on incredible years teacher classroom management training programme in northwest wales. Journal of Children's Services, 2(3), 15-26. https://doi.org/10.1108/17466660200700023

Kerr, M. N., \& Nelson, M. C. (1998). Strategies for managing behavivor problems in the classroom (3rd edition). Upper Saddle River, NJ: Merril Prentice Hall.

Kırcaali-İftar, G. (1998). Kaynaştırma ve destek özel eğitim hizmetleri "Özel gereksinimli bireyler ve özel eğitim". Eskisehir: Anadolu Üniversitesi Yayınları.

Kurt, O. (2012). Davranış arttırma ve azaltma yöntemleri. In E. Tekin İftar (Ed.), Eğitim ve davranış bilimlerinde tek denekli araştırmalar (s. 41-68). Ankara: Türkiye Psikologlar Derneği Yayınları.

Lindsay, G. (2007). Educational psychology and the effectiveness of inclusive education/ mainstreaming. British Journal of Educational Psychology, 77(1), 1-24. https://doi.org/10.1348/000709906X156881

Lyon, C. S., \& Lagarde, R. (1997). Tokens for success. Using the graduated reinforcements system. Teaching Exceptional Children, 29(6), 52-58. https://doi.org/10.1177/004005999702900612

Maag, J. W. (1999). Behavior management from theoretical implications to practial applications. Londra: Singular Publishing Group.

Maggin, D. M., Chafouleas, S. M., Goddart, K. M., \& Johnson, A. H. (2011). A systematic evaluation of token ecomonies as a classroom mamagement tool for students with challenging behavivor. Journal of School Psychology, 49, 529-554. https://doi.org/10.1016/j.jsp.2011.05.001

Matson, J. L., \&Boisjoli, J. A. (2009). The token economy for children intellectual Disability and/or autism: A review. Research in Developmental Disabilities, 30, 240-248. https://doi.org/10.1016/j.ridd.2008.04.001

Odom, S. L. (2000). Preschool inclusion: What we know and where we go from here. Topics in Early Childhood Special Education, 20(1), 20-27. https://doi.org/10.1177/027112140002000104

Odom, S. L., \& McEvoy, M. A. (1990). Mainstreaming at the preschool level: Potential barriers and tasks for the field. Topics in Early Childhood Special Education, 10(2), 48-61. https://doi.org/10.1177/027112149001000205

Olçay, G. S., \&Vuran, S. (2015). Normal sınıflara devam eden özel gereksinimli öğrencilerin kaynaştırma uygulamasına ilişkin görüşleri ve karşılaştıkları sorunlar. Eğitim ve Bilim, 40(180), 169-195.

Özyürek, M. (2001). Sinıf yönetimi. Ankara: Karatepe Yayınları.

Rafferty, Y., Piscitelli, V., \& Boettcher, C. (2003). The impact of inclusion on language development and social competence among preschoolers with disabilities. Exceptional Children, 69(4), 467-479. https://doi.org/10.1177/001440290306900405

Saracho, O. N. (1998). A study of the roles early childhood teachers. Early Childhood Education Journal, 38, 43-56.

Scheuermann, B., \& Webber, J. (2002). Autism. Teaching does make a difference. Canada: Wadsworth Thomson 
Learning.

Schloss, P. J., \& Smith, M. A. (1994). Applied behavivor analysis in the classroom. MA: Ally and Bacon.

Sturney, P., \&Fitzer, A. (2007). Autism spectrum disorders. Applied behavior analysis, evidence and Practice. Texas: Pro-ed.

Sucuoğlu, B., Demirtaşl1, N., \& Güner, N. (2009). Kaynaştırma sınıflarında çalışan sınıf öğretmenlerinin önleyici sınıf yönetimi bilgi ve becerilerinin değerlendirilmesi (2008-2009) Tübitak Destekli Araştırma Projesi, No: $108 \mathrm{~K}-183$.

Sulzer Azaroff, B., \& Mayer, G. R. (1991). Behavivor analysis for lasting change. Foth Wort, IN: Rinehart and Winston

Tarbox, R. S. F., Ghezzi, P. M., \& Wilson, G. (2006). The effects of token reinforcement on attending in a young child with autism. Behavioral Interventions, 21, 155-164. https://doi.org/10.1002/bin.213

Tekin-İftar, E., \& Kırcaali-İftar, G. (2004). Özel ĕgitimde yanlışsız ögretim yöntemleri. Ankara: Nobel Yayın Dağıtım.

Tekin-İftar, E., \& Kırcaali-İftar, G. (2012). Özel eğitimde yanlışsız öğretim yöntemleri (1. baskı). Ankara: Vize Basım Yayın.

Uysal, A. (2001). Zihinsel özürlü özel sınıf ögrrencilerine ögretmenlerinden dönüt ve/veya pekiştireç talep etmeyi ögretmenin etkileri. (doctorate dissertation). Anadolu Üniversitesi Eğitim Bilimleri Enstitüsü, Eskisehir, Türkiye.

Vuran, S., \& Olçay Gül, S. (2017). In Uygulamalı davranış analizi. S. Vural (Ed.), Uygun davranışların azaltılması (s. 76-94). Ankara: Atalay BasinYayin.

Webber, J., \& Scheuermann, B. (2008). Educating students with autism: A quick start manual. Austin, Texas: Pro-Ed.

Wolery, M., Bailey, D. B., \&Sugai, G. M. (1988). Effective teaching principles and procedures of applied behavior analyis for exceptional students. Boston: Ally and Bacon.

Yücesoy, Ö. Ş. (2013). Okul öncesinde kaynaştırma. In B. Sucuoğlu, \& H. Bakkaloğlu (Eds.), Okul öncesi sınıflarında sınıf yönetimi ve problem davranışların kontrolü (p.p. 193-260). Ankara: Kök Yayıncılık

\section{Copyrights}

Copyright for this article is retained by the author(s), with first publication rights granted to the journal.

This is an open-access article distributed under the terms and conditions of the Creative Commons Attribution license which permits unrestricted use, distribution, and reproduction in any medium, provided the original work is properly cited. 